\title{
Study of 1,4-Dioxane Intake in the Total Diet Using the Market- Basket Method
}

\author{
Tetsuji Nishimura, ${ }^{*, a}$ Seiichiro Iizuka, ${ }^{b, 1}$ Nobuyuki Kibune, ${ }^{b, 2}$ and Masanori Ando ${ }^{a}$ \\ ${ }^{a}$ Division of Environmental Chemistry, National Institute of Health Sciences, 1-18-1 Kamiyoga, Setagaya-ku, Tokyo 158-8501, Japan \\ and ${ }^{b}$ Section of Applied Testing, Japan Food Research Laboratories Osaka Branch, 3-1 Toyotsu-cho, Suita-shi, Osaka 564-0051, Japan
}

(Received October 23, 2003; Accepted October 31, 2003)

1,4-Dioxane has been classified by the US Environmental Protection Agency and the International Agency for Research on Cancer as a compound that may be carcinogenic in humans. Although there are several reports of 1,4-dioxane being detected in the environment, such as in tap water, there have been few reports on the content of 1,4-dioxane in food. We therefore studied the intake of 1,4-dioxane in food based on the average intake of food in the Kanto area of Japan as reported by the Ministry of Health, Labor and Welfare. The food was cooked in the normal manner and then homogenized in a mixer. A $20 \mathrm{~g}$ of sample of the homogenate was added to a solution of the purified water with $0.2 \mu \mathrm{g}$ of 1,4-dioxane- $\mathrm{d}_{8}$ as a surrogate and the $200 \mathrm{ml}$ azeotropic solution was recovered using the steam distillation method. This solution was applied to a pair of active carbon solid-phase cartridges and the analyte was eluted from each cartridge with dichloromethane. The eluted solution was prepared for gas chromatographic/mass spectrometric analysis by reduction to a volume of $1 \mathrm{ml}$ under a gentle stream of nitrogen. The detection limit of the analysis was $2 \mu \mathrm{g} /$ kg. We found that the 1,4-dioxane content of 12 food groups ranged between $2 \mu \mathrm{g} / \mathrm{kg}$ and $15 \mu \mathrm{g} / \mathrm{kg}$. From these results, the total daily intake of 1,4-dioxane was calculated to be $0.440 \mu \mathrm{g}$. An intake of this magnitude corresponds to $0.055 \%$ of the calculated total daily intake (TDI) $(16 \mu \mathrm{g} / \mathrm{kg}$ body weight/day). This study indicates that the amount of 1,4-dioxane intake contributed by food is very low and that this value does not represent a potential problem as it does not raise the risk of carcinogenesis.

\footnotetext{
${ }^{1}$ Present Address: Section of Trace Analysis, Japan Food Research Laboratories Tama Laboratory, 6-11-10, Nagayama, Tama-shi, Tokyo 206-0025, Japan

${ }^{2}$ Present Address: Section of Chemical Analysis, Japan Food Research Laboratories Osaka Branch, 3-1 Toyotsu-cho, Suitashi, Osaka 564-0051, Japan

*To whom correspondence should be addressed: Division of Environmental Chemistry, National Institute of Health Sciences, 1-18-1 Kamiyoga, Setagaya-ku, Tokyo 158-8501, Japan. Tel. \& Fax: +81-3-3700-9346; E-mail; nishimur@nihs.go.jp
}

Key words — 1,4-dioxane, total diet, risk

\section{INTRODUCTION}

1,4-Dioxane is used extensively as an industrial solvent in dyes, paints, lacquers, varnishes, oils, waxes, and resins and is also added as a stabilizer to chlorinated solvents. ${ }^{1)}$ 1,4-Dioxane is highly soluble in water, forming an azeotropic mixture, and when discharged into the atmosphere it returns to the surface as rainwater. As a property of its low adsorption to soil, 1,4-dioxane then permeates into the groundwater and causes water pollution over the long term. Therefore 1,4-dioxane has the potential to cause widespread contamination of the environment. There are reports of 1,4-dioxane being detected in river water at levels between 0.1 and $16.0 \mathrm{mg} / \mathrm{l}$, and in groundwater at a maximal concentration of $94.8 \mathrm{mg} / \mathrm{l}$ in Japan. ${ }^{2)}$ Several other studies have also shown high levels of 1,4-dioxane pollution in groundwater. ${ }^{2-4)}$ As the removal of 1,4-dioxane in water purification systems is difficult, these findings raise concerns regarding chronic exposure to 1,4-dioxane in drinking water.

1,4-Dioxane has been classified as a carcinogenic compound by both the USA Environmental Protection Agency ${ }^{5)}$ and the International Agency for Research on Cancer (IARC). ${ }^{6}$ Long-term oral administration of 1,4-dioxane has been shown to cause tumors in the liver and gallbladder in guinea pigs, ${ }^{7)}$ and in the nasal cavity and liver of rats. ${ }^{8-11)} 1,4-\mathrm{Di}-$ oxane has also demonstrated promoter activity in studies in mice using a two-stage carcinogenic test. ${ }^{12}$

Levels of 1,4-dioxane between $0.2 \mathrm{mg} / \mathrm{l}$ and $1.5 \mathrm{mg} / \mathrm{l}$ were also detected in tap water samples collected during 1995 and 1996 from six cities in Kanagawa prefecture, Japan. ${ }^{13)}$ This finding raises the possibility that food may also have become con- 
taminated. Although 1,4-dioxane is now included in the quality standards for drinking water in Japan, there have been few reports on the contents and intake of 1,4-dioxane in food. To safeguard human health, it is important to determine the Japanese intake levels of 1,4-dioxane through food. This paper describes a study on the intake of 1,4-dioxane through food in Japan using the market-basket method.

\section{MATERIALS AND METHODS}

\section{Chemicals — 1,4-Dioxane was purchased from} Tokyo Chemical Industry Co. Ltd. (Tokyo, Japan), 1,4-dioxane-d ${ }_{8}$ from Sigma-Aldrich Co. Ltd. (St. Louis, MO, U.S.A.), dichloromethane from Kanto Chemical Industry Co. Ltd. (Tokyo, Japan), ethanol from Katayama Chemical Industry Co. Ltd. (Osaka, Japan), acetonitrile and acetone from Wako Chemical Industry Co. Ltd. (Osaka, Japan), and the antifoaming agent silicon TAS730 from Toshiba Silicon Co. Ltd. (Tokyo, Japan). All solvents were of the highest reagent grade. Purified water was prepared using a Milli-Q water purification PSS20 system (Millipore Corp., Bedford, MA, U.S.A.).

Preparation of Standard Solutions - A stock solution of 1,4-dioxane $(1 \mathrm{mg} / \mathrm{ml})$ was prepared in dichloromethane, and a stock solution of 1,4-dioxane- $\mathrm{d}_{8}(10 \mathrm{mg} / \mathrm{ml})$ was prepared in ethanol. The stock solution of 1,4-dioxane- $\mathrm{d}_{8}$ was then diluted with dichloromethane to a final concentration of $40 \mu \mathrm{g} /$ $\mathrm{ml}$. The 1,4-dioxane stock solution was diluted with dichloromethane and used to prepare the working standard solutions containing 1,4-dioxane- $\mathrm{d}_{8} 0.2 \mu \mathrm{g} /$ $\mathrm{ml}$ in the concentration range of $0.04-1 \mu \mathrm{g} / \mathrm{ml}$. A solution of 1,4-dioxane- $\mathrm{d}_{8} 2 \mu \mathrm{g} / \mathrm{ml}$ was prepared in acetonitrile and was added to samples to determine the recovery rate of the analytical procedure.

Preparation of Food Samples — The food ingredients were purchased at a general market in Setagaya-ku, Tokyo, Japan in April and May 2000. The quantity of each food item was determined on the basis of the results of the average intake of food in the Kanto area reported by the Ministry of Health, Labor and Welfare (Table 1), using six times the weight of each food group for preparation. Food was cooked in a manner similar to that used in normal homes and was then homogenized in a mixer (Hamilton Beach/Proctor-Silex, Inc., Washington, NC, U.S.A., Model 911). Food that was difficult to homogenize was made uniform by the addition of purified water. In the preparation and cooking of the food, utensils made from wood, aluminum, fluororesin iron, and plastic were used and included items such as a chopping block, pots, and pans. These utensils were washed in a manner similar to that used in normal homes, and tap water was used for cooking. The food homogenates of each group were stored in glass bottles with silicon seals and were kept frozen at $-20^{\circ} \mathrm{C}$ until analyzed.

Extraction of 1,4-Dioxane —— A $20 \mathrm{~g}$ of sample of each homogenate was placed in a $500 \mathrm{ml}$ eggplant-type flask, followed by the addition of $150 \mathrm{ml}$ of purified water and $100 \mu \mathrm{l}$ of $2 \mu \mathrm{g} / \mathrm{ml}$ 1,4-dioxane$\mathrm{d}_{8}$ solution. Two hundred milliliters of aqueous solution was recovered from the sample mixture using the steam distillation method. This solution was then passed through a pair of active carbon solidphase cartridges equilibrated with $20 \mathrm{ml}$ of dichloromethane, $30 \mathrm{ml}$ of acetone, and then $40 \mathrm{ml}$ of purified water. Extraction of the water samples was carried out at a flow rate of $10 \mathrm{ml} / \mathrm{min}$. After the water sample had passed through the cartridges, the cartridges were washed with $5 \mathrm{ml}$ of purified water at the same flow rate. Dried nitrogen gas was then passed through the cartridges for $30 \mathrm{~min}$, and the analyte was eluted from the each cartridge, with the cartridge for the water adsorption attached at the bottom with dichloromethane $3 \mathrm{ml}$. The cartridge for water adsorption was washed with dichloromethane $20 \mathrm{ml}$ prior to use. The eluted solution was then reduced to a volume of $1 \mathrm{ml}$ under a gentle stream of nitrogen for gas chromatographic/mass spectrometric (GC/MS) analysis.

GC/MS Analysis — An Agilent 6890/5973N (Agilent Technologies Inc., Palo Alto, CA, U.S.A.) instrument was used for the GC/MS analysis, with separation carried out on a SPB-624 capillary column $(60 \mathrm{~m} \times 0.25 \mathrm{~mm}$ i.d. $\times 1.4-\mu \mathrm{m}$ film thickness $)$ (Sigma-Aldrich Co. Ltd.). Helium was used as the carrier gas with a column flow rate of $1 \mathrm{ml} / \mathrm{min}$ in the constant flow mode. The column temperature was kept at $60^{\circ} \mathrm{C}$ for $1 \mathrm{~min}$, then programmed to increase by $5^{\circ} \mathrm{C}$ per minute to $130^{\circ} \mathrm{C}$ and then $20^{\circ} \mathrm{C}$ per minute to $230^{\circ} \mathrm{C}$. Pulsed splitless injection was used with a pulse pressure of $400 \mathrm{kPa}(1 \mathrm{~min})$. The ion source temperature was kept at $230^{\circ} \mathrm{C}$ with the mass spectrometer operated in the EI mode. In the selected ion monitoring (SIM) mode, the monitoring ions were 58 and 88 for 1,4-dioxane and 64 and 96 for 1,4-dioxane-d $\mathrm{d}_{8}$. The injection volume was $2.0 \mu \mathrm{l}$. A calibration curve was prepared from the ratio of the peak height of 1,4-dioxane and 1,4-di- 
Table 1. List of Food in the Total Diet Study

\begin{tabular}{|c|c|c|c|}
\hline Group & Food Group & Food & Daily Intake $(\mathrm{g})$ \\
\hline \multirow[t]{2}{*}{ I } & Rice & Rice & 149.0 \\
\hline & Rice products & Rice vermicelli & 4.1 \\
\hline \multirow[t]{13}{*}{ II } & Barley & Oatmeal & 0.2 \\
\hline & Flour & Wheak flour & 8.3 \\
\hline & Bread & Bread & 36.1 \\
\hline & Sweet bun & Bean-jam bun & 8.6 \\
\hline & Noodles & Japanese wheat noodles & 39.2 \\
\hline & Noodles, macaroni & Buckwheat & 6.5 \\
\hline & Instant noodles & Instant noodles & 3.7 \\
\hline & Grain & Cornflakes & 2.5 \\
\hline & Seed & Crushed almonds & 2.0 \\
\hline & Sweet potato & Sweet potato & 8.6 \\
\hline & Potato & Potato & 35.9 \\
\hline & Tubers and roots & Taro & 10.4 \\
\hline & Product of tubers and roots & Konjak & 13.5 \\
\hline \multirow[t]{9}{*}{ III } & Sugar & Granulated sugar & 7.6 \\
\hline & Jam & Strawberry jam & 1.6 \\
\hline & Candy & Caramel & 0.3 \\
\hline & Rice cracker & Rice cracker & 2.0 \\
\hline & Cake & Pound cake & 4.0 \\
\hline & Biscuit & Biscuit & 3.3 \\
\hline & Other snacks & Japanese fried-dough cookies & 15.0 \\
\hline & & Azuki bean jelly & \\
\hline & & Chocolate & \\
\hline \multirow[t]{5}{*}{ IV } & Butter & Butter & 1.3 \\
\hline & Margarine & Margarine & 1.7 \\
\hline & Vegetable oil & Soybean oil & 10.4 \\
\hline & Animal oil & Lard & 0.2 \\
\hline & Mayonnaise & Dressing & 5.7 \\
\hline \multirow[t]{5}{*}{ V } & Soybean paste & Soybean paste & 12.8 \\
\hline & Beancurd (tofu) & Beancurd (tofu) & 35.4 \\
\hline & Product of beans & Deep-fried beancurd & 6.0 \\
\hline & Soybean products & Freeze-dried beancurd & 9.9 \\
\hline & Beans & & 2.6 \\
\hline \multirow[t]{8}{*}{ VI } & Citrus & Navel orange & 30.6 \\
\hline & Apple & Apple & 26.6 \\
\hline & Banana & Banana & 7.7 \\
\hline & Strawberry & Strawberry & 0.2 \\
\hline & Fruit & Watermelon & 49.0 \\
\hline & & Loquat & \\
\hline & & Japanese apricot & \\
\hline & Juice & Tomato juice & 17.0 \\
\hline \multirow[t]{7}{*}{ VII } & Carrot & Carrot & 24.0 \\
\hline & Spinach & Spinach & 19.7 \\
\hline & Green pepper & Green pepper & 4.7 \\
\hline & Tomato & Tomato & 21.7 \\
\hline & Green and yellow vegetables & Broccoli & 30.8 \\
\hline & & Celery & \\
\hline & & Okra & \\
\hline
\end{tabular}


Table 1. Continued

\begin{tabular}{|c|c|c|c|}
\hline Group & Food Group & Food & Daily Intake (g) \\
\hline \multirow[t]{12}{*}{ VIII } & Japanese radish (daikon) & Japanese radish & 36.0 \\
\hline & Onion & Onion & 27.7 \\
\hline & Cabbage & Cabbage & 24.8 \\
\hline & Cucumber & Cucumber & 14.7 \\
\hline & Napa cabbage & Napa cabbage & 18.2 \\
\hline & Vegetables & Burdock (gobo root) & 44.5 \\
\hline & & Beansprouts & \\
\hline & & Eggplant & \\
\hline & Pickles & Pickles (nozawa-na) & 6.5 \\
\hline & Pickled Japanese radish & Fukujinn-zuke & 15.5 \\
\hline & Mushrooms & Mushrooms & 12.8 \\
\hline & Seaweeds & Green laver & 5.6 \\
\hline \multirow[t]{9}{*}{ IX } & Soy sauce & Soy sauce & 19.9 \\
\hline & Sauces & Ketchup & 5.4 \\
\hline & Salt & Salt & 1.3 \\
\hline & Seasoning & Sauce & 11.6 \\
\hline & Sake & Sake & 15.5 \\
\hline & Beer & Beer & 64.2 \\
\hline & Liquor & Wine & 12.4 \\
\hline & Soft drinks & Soft drinks & 69.4 \\
\hline & & Tea & \\
\hline \multirow[t]{15}{*}{$X$} & Salmon and trout & Salmon & 3.3 \\
\hline & Tuna & Tuna & 8.8 \\
\hline & Bream and flatfish & Flatfish & 8.0 \\
\hline & Horse mackerel and sardine & Horse mackerel & 12.5 \\
\hline & Raw fish & Ayu & 6.4 \\
\hline & & Kisu & \\
\hline & & Halfbeak & \\
\hline & Cuttlefish, octopus, and crab & Octopus & 13.6 \\
\hline & Shellfish & Scallop & 4.7 \\
\hline & Salted fish & Salted cod & 8.7 \\
\hline & Dried fish & Dried sardine & 9.5 \\
\hline & Canned fish & Bonito & 2.9 \\
\hline & Cooked fish & Smelt & 0.7 \\
\hline & Cooked fish paste & Hannpen & 12.2 \\
\hline & Fish product & Fish sausage & 0.3 \\
\hline \multirow[t]{7}{*}{ XI } & Beef & Beef & 21.7 \\
\hline & Pork & Pork & 31.9 \\
\hline & Chicken & Chicken & 19.8 \\
\hline & Whale & & 0.0 \\
\hline & Other animal meat & Lamb & 0.9 \\
\hline & Ham and sausage & Pork loin ham & 11.0 \\
\hline & Eggs & Chicken eggs & 38.3 \\
\hline \multirow[t]{4}{*}{ XII } & Milk & Milk & 116.4 \\
\hline & Cheese & Cheese & 2.8 \\
\hline & Daiury products & Yoghurt & 21.1 \\
\hline & Others & Sake sediment & 5.8 \\
\hline
\end{tabular}


oxane- $\mathrm{d}_{8}$. Quantitative analysis of the food samples was carried out using methodology identical to that used in the preparation of the calibration curve. ${ }^{13)}$

\section{RESULTS AND DISCUSSION}

\section{Detection Limit in Food Samples}

The minimum detection level of 1,4-dioxane- $\mathrm{d}_{8}$ added as an internal standard was $0.04 \mu \mathrm{g} / \mathrm{l}(\mathrm{S} / \mathrm{N}=$ 10). The minimum detection limit of 1,4-dioxane in the prepared food was calculated to be $2 \mu \mathrm{g} / \mathrm{kg}$ using the following formula: $(0.04 \mu \mathrm{g} / \mathrm{l} \times 1 \mathrm{ml}) / 20 \mathrm{~g}=$ $0.002 \mu \mathrm{g} / \mathrm{g}=2 \mu \mathrm{g} / \mathrm{kg}$, in which $1 \mathrm{ml}$ indicates the final volume for GC/MS analysis and $20 \mathrm{~g}$ indicates the weight of the food homogenate.

\section{Recovery Test of 1,4-Dioxane}

The concentration of 1,4-dioxane in the purified water and tap water used in the analysis and in the preparation of the food samples was less than $0.04 \mu \mathrm{g} / \mathrm{ml}$. This level represented the minimum detection limit when the analysis was carried out in the manner used for the food samples.

After the addition of 1,4-dioxane $0.2 \mu \mathrm{g}$ and 1,4dioxane- $\mathrm{d}_{8} 1 \mu \mathrm{g}$ to $4 \mathrm{~g}$ of the prepared food samples, the recovery rate of 1,4-dioxane was obtained using the method described in the MATERIALS AND METHODS section. Table 2 shows that the recovery rate was between $99 \%$ and $111 \%$ in the 12 groups. These results indicate there was no problem with the efficiency of extraction when 1,4-dioxane was added to the food samples at a concentration $<0.2 \mu \mathrm{g} / 4 \mathrm{~g}(50 \mu \mathrm{g} / \mathrm{kg})$.

\section{Content of 1,4-Dioxane in the Food Samples}

The extraction of 1,4-dioxane from each $20 \mathrm{~g}$ prepared food sample was carried out according to the method described in the MATERIALS AND METHODS section. Table 3 shows that the content of 1,4-dioxane in the 12 food groups was between $2 \mu \mathrm{g} / \mathrm{kg}$, the detection limit of the analysis, and $15 \mu \mathrm{g} /$ $\mathrm{kg}$. If the food sample was difficult to homogenize after cooking, an appropriate quantity of purified water was added to achieve homogeneity (i.e., groups I, II, III, and X in Table 4). The weight of the food used for the extraction of 1,4-dioxane before and after cooking was then calculated.

The intake of 1,4-dioxane was calculated based on the average intake of food in the Kanto area as reported by the Ministry of Health, Labor and Welfare. For example, the calculation in group II in-
Table 2. Recovery Rate of 1,4-Dioxane Added to Food Samples

\begin{tabular}{cc}
\hline \hline Group & Recovery Rate $(\%)$ \\
\hline I & 104 \\
II & 101 \\
III & 105 \\
IV & 101 \\
V & 106 \\
VI & 100 \\
VII & 100 \\
VIII & 100 \\
IX & 99 \\
X & 102 \\
XI & 104 \\
XII & 111 \\
\hline
\end{tabular}

Table 3. Content of 1,4-Dioxane in Food Samples

\begin{tabular}{cc}
\hline \hline Group & Content $(\mathrm{mg} / \mathrm{kg})$ \\
\hline I & ND \\
II & 6 \\
III & 6 \\
IV & 8 \\
V & 3 \\
VI & 4 \\
VII & 3 \\
VIII & 8 \\
IX & 7 \\
X & 5 \\
XI & 6 \\
XII & 13 \\
\hline \multicolumn{2}{c}{ ND: not detectable. }
\end{tabular}

cluded a food sample of $1061.6 \mathrm{~g}$ that was added to $600.0 \mathrm{~g}$ of purified water for cooking and then homogenized. The actual weight of food for extraction was $18.34 \mathrm{~g}$ calculated as $(20 \mathrm{~g} / 1157.5 \mathrm{~g}) \times$ $(1061.6 \mathrm{~g}+600.0 \mathrm{~g}) \times\{1061.6 \mathrm{~g} /(1061.6 \mathrm{~g}+$ $600.0 \mathrm{~g})\}$. Since the intake of group II food was $175.5 \mathrm{~g}$, the intake of 1,4-dioxane from food in this group was $0.057 \mu \mathrm{g}$ calculated as $(175.5 \mathrm{~g} / 18.34 \mathrm{~g})$ $\times 6 \mu \mathrm{g} / \mathrm{kg} \times(1 / 1000)$. From the results of the content of each group in Table 4, the daily total intake of 1,4-dioxane from food was calculated to be $0.440 \mu \mathrm{g}$.

\section{Risk from 1,4-Dioxane in Food}

There is evidence that long-term oral administration of 1,4-dioxane causes hepatic and nasal cavity tumors in rodents, ${ }^{8-12)}$ and accordingly the IARC has classified 1,4-dioxane as a group $2 \mathrm{~B}$ carcino- 
Table 4. Intake of 1,4-Dioxane from Food

\begin{tabular}{cccccccc}
\hline \hline Group & $\begin{array}{c}\text { Weight before } \\
\text { Cooking } \\
(\mathrm{g})\end{array}$ & $\begin{array}{c}\text { Weight of Added } \\
\text { Water } \\
(\mathrm{g})\end{array}$ & $\begin{array}{c}\text { Weight after } \\
\text { Cooking } \\
(\mathrm{g})\end{array}$ & $\begin{array}{c}\text { Actual Weight of } \\
\text { Food for Extraction } \\
(\mathrm{g})\end{array}$ & $\begin{array}{c}\text { Intake of } \\
\text { Food } \\
(\mathrm{g})\end{array}$ & $\begin{array}{c}\text { Content in } \\
\text { Food }\end{array}$ & $\begin{array}{c}\text { Intake of } \\
1,4-\text { Dioxane } \\
(\mu \mathrm{g} / \mathrm{kg})\end{array}$ \\
\hline I & 894.0 & 1143.3 & 1715.0 & 10.43 & 153.1 & ND & 0.000 \\
II & 1061.6 & 600.0 & 1157.5 & 18.34 & 175.5 & 6 & 0.057 \\
III & 202.8 & 100.0 & 202.8 & 20.00 & 33.8 & 6 & 0.010 \\
IV & 1114.0 & & 1114.0 & 20.00 & 19.3 & 8 & 0.008 \\
V & 727.9 & & 400.2 & 36.38 & 66.7 & 3 & 0.006 \\
VI & 981.5 & & 981.5 & 20.00 & 131.1 & 4 & 0.026 \\
VII & 605.4 & & 609.0 & 19.88 & 100.9 & 3 & 0.015 \\
VIII & 1237.8 & & 1143.7 & 21.65 & 206.3 & 8 & 0.076 \\
IX & 416.4 & & 416.4 & 20.00 & 199.7 & 7 & 0.070 \\
X & 550.2 & 300.0 & 524.0 & 21.00 & 91.6 & 5 & 0.022 \\
XI & 608.9 & & 908.9 & 13.40 & 123.6 & 6 & 0.055 \\
XII & 1019.4 & & 1019.4 & 20.00 & 146.1 & 13 & 0.095 \\
\hline
\end{tabular}

a) $1: 20 \mathrm{~g}$ was used for extraction.

gen. $\left.{ }^{6}\right)$ With regard to a cancer endpoint, a total daily intake (TDI) of $16 \mu \mathrm{g}$ of 1,4-dioxane/kg body weight/ day has been calculated by applying an uncertainty factor of 1000 that incorporates 100 for inter- and intraspecies variation and 10 for nongenotoxic carcinogenicity to the no observed adverse effect level of $16 \mu \mathrm{g} / \mathrm{kg}$ body weight/day, as found in a longterm study involving drinking water in rats. ${ }^{14,15)}$ The $0.440 \mu \mathrm{g}$ intake of 1,4-dioxane we measured in our study corresponds to $0.055 \%$ of the calculated TDI $(0.440 \mu \mathrm{g} /\{16 \mu \mathrm{g} / \mathrm{kg}$ body weight/day $\times 50 \mathrm{~kg}\})$. We therefore conclude that the intake of 1,4-dioxane from food appears to be very low and that this value does not increase the risk of carcinogenicities.

Acknowledgements We thank Mrs. Emi HayabeHirakawa for help in the preparation of the food samples. This work was supported by Grants-in-Aid from the Ministry of Health, Labor and Welfare of Japan.

\section{REFERENCES}

1) Budavari, S. (Ed.) (1996) The Merk Index, 12 th edn., Merk \& Co. Inc., Whitehouse Station, NJ, p. 3358.

2) Abe, A. (1999) Distribution of 1,4-dioxane in relation to possible sources in the water environment. Sci. Total Environ., 227, 41-47.

3) Ministry of the Environment (Planning and Coordination Bureau S) (1998) Outline of 1998 study results on designated chemicals, pp. 26-37.

4) Magara, Y., Sudo, R., Nakamuro, K., Yuasa, A., Abe,
A., Sato, C., Sekine, H., Oosawa, E., Terasawa, K., Kawachi, T., Shiozaki, J., Aizawa, T., Ando, M. and Nishimura, T. (1998) Comprehensive approaches to the management of surfactants and related chemicals in water sources and drinking water treatment processes. In Environmental Research in Japan, 1998 (National Resarch Institutes of Government Ministries and Agencies, Eds.), No. 1, pp. 8.1-8.33.

5) US EPA (1993) Integrated Risk Information System (IRIS) on 1,4-Dioxane. Environmental Criteria and Assessment Office (Office of Research and Development, Eds.), Cincinnati, $\mathrm{OH}$.

6) IARC (1999) IARC Monographs on the Evaluation of Carcinogenic Risks to Humans, Vol. 71, Pt 2, Reevaluation of Some Organic Chemicals, Hydrazine and Hydrogen Peroxide, World Health Organization, Lyon, pp. 589-602.

7) Hoch-Ligeti, C. and Argus, M. F. (1970) Effect of carcinogens on the lung of guinea pigs. Morphology of experimental respiratory carcinogenesis. In Publication No. CONF-700401 (Nettesheim, P., Hanna, M. G., Jr. and Deatherage, J. W., Jr., Eds.), Technical Information Service, U.S. Department of Commerce, Springfield, VA, pp. 267-279.

8) Argus, M. F., Arcos, J. C. and Hoch-Ligeti, C. (1965) Studies on the carcinogenic activity of proteindenaturing agents: hepatocarcinogenicity of dioxane. J. Natl. Cancer Inst., 35, 949-958.

9) Argus, M. F., Sohal, R. S., Bryant, G. M. and HochLigeti, C. (1973) Dose-response and ultrastructural alterations in dioxane carcinogenesis. Influence of methylchlolanthrene on acute toxicity. Eur. J. Cancer, 9, 237-243.

10) Hoch-Ligeti, C., Argus, M. F. and Arcos, J. C. (1970) Induction of carcinomas in the nasal cavity of rats 
by dioxane. Br. J. Cancer, 24, 165-167.

11) Kociba, R. J., McCollister, S. B., Park, C., Torkelson, T. R. and Gehring, P. J. (1974) 1,4-Dioxane 1. Results of a 2-year ingestion study in rats. Toxicol. Appl. Pharmacol., 30, 275-286.

12) King, M. E., Shefiner, A. M. and Bates, R. R. (1973) Carcinogenesis bioassay of chlorinated dibenzodioxins and related chemicals. Environ. Health Prespect, 5, 163-170.

13) Abe, A. (1997) Determination method for 1,4- dioxane in water samples by solid phase extractionGC/MS. J. Environ. Chem., 7, 95-100 (in Japanese).

14) Kochiba, R. J., McCollister, S. B., Park, C., Torkelson, T. R. and Gehring, P. J. (1974) 1,4Dioxane. I. Results of a 2-year ingestion study in rats. Toxicol. Appl. Pharmacol., 60, 287-300.

15) World Health Organization (Ed.), WHO Guideline for Drinking-water Quality, 3rd. edn., World Health Organization, (in press). 